\title{
Chapter 9 \\ Key Factors to Educational Continuity and Success of Ciganos in Portugal
}

\author{
Olga Magano and Maria Manuela Mendes
}

\begin{abstract}
The goal of this article is to analyse the impact of specific public policies on the school trajectories of socially vulnerable Ciganos (Gypsies/Roma) who reside/live in the Metropolitan Areas of Lisbon and Porto. Through carrying out qualitative research, the analysis of key factors will allow us to understand the reasons behind school continuity and educational success of Ciganos, as well as the identity (re)configuration processes associated with the education paths of these individuals. We find that trajectories are not only intertwined with public policies and programmes, but also with other explanatory factors inherent to the individual, to the type of support he/she receives from his/her family, the presence of key figures in their lives, and the importance of peers and institutional factors inherent to the way public schools operate.
\end{abstract}

Keywords Ciganos/Roma $\cdot$ Education $\cdot$ Public policies $\cdot$ Social inequalities · Portugal

The open access publication of this chapter was funded by Portuguese National Funds through the Fundação para a Ciência e a Tecnologia, R\&D Unit UIDB/03126/2020.

O. Magano ( $\square)$

Universidade Aberta, Lisbon, Portugal

University Institute of Lisbon (ISCTE-IUL), Centre for Research and Studies in Sociology

(CIES-IUL), Lisboa, Portugal

e-mail: olga.magano@uab.pt

M. M. Mendes

University Institute of Lisbon (ISCTE-IUL), Centre for Research and Studies in Sociology (CIES-IUL), Lisboa, Portugal

Faculty of Architecture, University of Lisbon, Lisbon, Portugal

(C) The Author(s) 2021

M. M. Mendes et al. (eds.), Social and Economic Vulnerability of Roma People, https://doi.org/10.1007/978-3-030-52588-0_9 


\section{Ciganos $^{1}$ and Education: the Background of a Mismatch}

The right to education, along with providing equal opportunities for all to access and succeed in school, as embodied in the Constitution of the Portuguese Republic (Articles 73-77), is of paramount importance in Portuguese society. The Basic Law of the Educational System (Law no. 46/86, of October 14) establishes the general framework of the Portuguese education system, advocating universal, compulsory and free basic education. Deriving from this educational reform, it was originally established that it be compulsory for all to attend schooling up until the ninth grade, or the age of 15. Law no. 85/2009, of August 27, however, changed this, making the completion of school up to the 12th grade, or the attending of school up until the age to 18, compulsory. Furthermore, all children would be required to start their pre-school education at the age of 5.

According to the National Education Council (2014, p. 22), "in 1991 the average schooling of Portuguese nationals was still close to the primary school level (grade 4 ), and still far from the ninth grade (obligatory since 1986) by 2011 ".

To tackle these issues, the programmes Educational Territories of Priority Intervention (TEIP) and the Integrated Education and Training Programme (PIEF) worth to be highlighted, created in 1996 and 1999, respectively. Currently under operation, the TEIP programme supervised by the Ministry of Education is guided by the main objectives of promoting educational success, combating indiscipline in school, early school leaving and absenteeism, offering educational guidance, helping transition from school to active life, as well as the articulation between school, family and community. The PIEF is a special measure that seeks to promote compulsory education.

Also worthy of being pointed out is the Escolhas (Choices) Programme, which, since its first generation inaugural work package in 2001, is currently carrying out its seventh generation package (2019-2021). The main objective of this programme is to promote the social inclusion of children and young people from vulnerable socioeconomic contexts, aiming to provide equal opportunities and to reinforce social cohesion. These measures are promoted by the Presidency of the Council of Ministers, falling under the supervision of the High Commission for Migrations. Many projects focus on the Metropolitan Areas of Lisbon (MAL) and Porto (MAP).

Also worth highlighting is the importance of the Social Integration Income (SII), a social policy instrument. Having the ultimate aim of reducing extreme poverty in Portugal, both of these measures were designed to support individuals or families in situations of serious economic need and at risk of social exclusion, providing a financial subsidy aimed at giving a person/family a means of purchasing basic needs. The SII is also meant to serve as an insertion programme that favours the social, professional and community integration of individual's/family members.

\footnotetext{
${ }^{1}$ We maintain the term in Portuguese, as it is still recognized and used by the Portuguese Ciganos themselves. In international context, the term can be understood as Portuguese Roma.
} 
Concerning Ciganos and their social and cultural identities and ways of being, there is often a lack of knowledge on the part of society-at-large, including teachers and social intervention professionals (Mendes and Magano 2016). With the onset of democracy in Portugal (April 25th, 1974), a new era began in relation to how the State started recognizing Ciganos, providing citizenship rights and dealing with matters pertinent to Ciganos. However, public policies are universal and there was no recognition of the Ciganos issue in Portugal. The first time that a reference to the situation of Ciganos is made National Action Plan for Social Inclusion (2008-2010) and as the target population in the Ethics Committee Parliamentary Report (CPESC 2009). Later, the National Strategy for the Integration of Ciganos Communities (ACIDI 2013) which for the first time placed this population on the political agenda, ${ }^{2}$ due to the imposition of the European Union on Member States (European Parliament 2011).

Despite the profusion of social and educational policies, the Ciganos in Portugal continue to have low levels of schooling and educational success, having high dropout and illiteracy rates. It is a population that possesses very low rates of education advancement when compared to non-Ciganos. The results from a survey applied to 1599 Ciganos living in mainland Portugal carried out in 2014 (Mendes et al. 2014, 2016) reveal the fact that $52 \%$ of the respondents did not complete or did not attend primary school at all. Also worthy of being highlighted is the fact that $27.1 \%$ did not know how to read or write.

In 2018, according the survey of Ministry of Education (DGEEC 2018) there exist high retention rates among Ciganos children and young people. In the universe of 10,349 Ciganos and specifically in academic year of 2016/2017, 48\% of Ciganos students have one or more retentions. and the high number of school drop-outs is very visible.

Building on the above, results deriving from a qualitative research project ${ }^{3}$ carried out between mid-2013 to the end of 2015, will be discussed in the sections to come, permitting the identification and understanding of some of the key factors for school continuity and educational success of Ciganos in Portugal.

\footnotetext{
${ }^{2}$ According to Marques (2013), given that the primary victims of racism in Portugal are the various "communities" of Ciganos found throughout the country, this implying that we are facing a sociological issue not only centring on Gypsies as victims of racism, but also the issue of problems associated with this "historical community's" participation as citizens within the broader society. It is what Bastos et al. (2007) describe as "Ciganofobia", carried out both by the State and by civil society, and reflected in the refusal to face the issue as a historical problem of discrimination directed at the Ciganos.

${ }^{3}$ Results presented are part of the research project Key factors to the success and continuity of schooling of Ciganos: individuals, families, and public policies, funded by Fundação para a Ciência e Tecnologia (the Portuguese National Funding Agency for Science, Research and Technology), ref. PTDC/IVC-PEC/4909/2012, developed in the context of a partnership between CIES-IUL (ISCTE-IUL) and CEMRI, Universidade Aberta.
} 


\section{Qualitative Approach to a Complex Social Phenomenon}

In carrying out this investigation project, the first step taken was to map the social intervention projects in progress and to establish profiles of the Ciganos living in the municipalities that compose the MAP (Metropolitan Area of Porto) and MAL respectively. This was followed by the selection of six neighbourhoods, three in each Metropolitan Area. A survey of local organisations, projects and interventions was carried out in each of these neighbourhoods and we also contacted the mediators and other technical coordinators responsible for local projects. A period of participant observation along with 36 in-depth interviews with these individuals where then conducted during an initial fieldwork period between November 2013 and March 2014.

The ethnographic work carried out in each neighbourhood was aimed at establishing a relationship of proximity and trust with the Ciganos who live in the respective neighbourhoods, and to participate in their individual/family daily lives. It was our intention to delve in an in-depth and comparative fashion into the living conditions and ways of life of our participants, as well as to observe relations established by them with local intervention institutions, schools and with their neighbours, be them Cigano or otherwise. We also set out to explore how they approach the places where they live, be it public or private, and the institutional spaces they frequent. Furthermore, we set out to ethnographically draw on the relations between the past and present in order to show changes and continuities in the lives of the Ciganos we accompanied and their families, this primarily in relation to learning and the valorisation of a school education. A particular look was also given to difficulties experienced by these individuals, and ways of overcoming them, focusing specifically on the support received, be that economic or otherwise. Our choice for this ethnographic method is justified by the fact that it allows a greater immersion in to the field and the people (Beaud and Weber 1997).

In the studied neighbourhoods, ethnographies were also carried out in selected number of schools. In the MAP, ethnographic work was carried out at a series of multi-grade level schools [agrupamento de escolas (AE) ${ }^{4}$ ] in 2 Group of Schools and 3 in the Metropolitan Area of Lisbon.

During our first fieldwork period, 73 semi-structured interviews were thus conducted with Ciganos who resided in our studied neighbourhoods (37 in the MAL; 36 in the MAP). The interviews focused on individual and family relationships, and education. A second fieldwork phase (between November 2014 and February 2015) was used to conduct nine focus groups (four in the MAL and five in the MAP). In total, 71 people participated in these groups, among them mediators, teachers and Ciganos. The objective of the focus groups was to gather participant's

\footnotetext{
${ }^{4}$ The Portuguese term Agrupamento de Escolas (AE) implies a grouping of schools with its own administrative and management bodies, consisting of multi-grade level, often based on a common pedagogical project.
} 
opinions and to discuss issues related to the schooling of Ciganos residing in our studied neighbourhoods. Data obtained through previously carried out interviews and observation work was used as the primary base of discussion.

\section{Representations of School and Schooling}

The ethnographies and interviews carried out with the selected Ciganos have shown that there have been important changes in the midst of this minority group in the last few decades, especially in the case of women. Concerning education, collected narratives show that, today, Ciganos parents accompany their children's schooling more closely, making it know that they will attend school meetings when called upon and make a point of accompanying the evolution of their children's schooling. In general, parents show that they are attentive to and interested in the development of their children's reading and writing capacities and abilities to do mathematics. Other school subjects, on the other hand, were often given little value by the parents.

The data collected points to generational differences when it comes to giving value to school attendance. Many of the parents of school-aged children interviewed also attended school until the secondary school years, thus they dedicate themselves to follow their children's schooling more so than previous generations.

It should also be noted that none of the Ciganos interviewed, who had either completed secondary education, or attended or completed post-secondary education, pursued their pathway straightforward regular schooling.

As far as expectations concerning their children, respondents claimed to value education for it is seen as a way for their children to get a job, permitting them to have a better life. Staying in school is, therefore, understood as a way to access work in the future. In conclusion, school and work combined are perceived as factors of social mobility, a finding that falls in line with results gathered in previous studies on non-employed Ciganos workers (Mendes and Magano 2016; Brüggemann 2014).

Reflecting upon themselves, our participants highlighted that, in many cases, school continuity occurred during adult life, outside the context of the normal schooling age-it occurred at different stages, as opportunities arose, revealing a connection with public policies and projects these individuals and their families were, or continue to be, involved in. One of the interviewees who recently finished his undergraduate degree, revealed how specific measures and public policies were decisive in his pursuit of further studies:

Up until the $10^{\text {th }}$ grade, I did normal schooling without ever failing. By $10^{\text {th }}$ grade, my father had died and my mother got very depressed so I left school. She could not go on and had to take care of her. I ended up going a long time without studying. Then, a few years ago, as I always had this desire to study, since I wanted to continue my studies, I did the New 
Opportunities programme ${ }^{5}$ having the perspective that it would help me advance professionally. (...) I didn't have grade 10 completed yet, I completed that and went on to complete grade 12 and went on to do psycho-technical tests to get into university. (Male, 28-years-old, undergraduate degree)

Even those Ciganos who never learnt to read or write, attended some type of training course at least once-indifferent of age or place of residence-of the courses provided by the Institute for Employment and Vocational Training (IEFP) or as part of the SII were most common. So even though various attempts have been made to bring these individuals closer to schooling and/or training, these have not played a structural role in the lives of these Ciganos. Manifestations of discontentment concerning the training programmes offered to them are frequent, and are often described as being of short duration, often either below or too far advanced of their knowledge and capabilities, or lacking the diversity in themes and content. More than that, the interviewees complained that they were not evaluated, neither positively nor properly, by the training placement workers (making them waste time and money, creating family friction, etc. and often not contributing to bettering their education or providing them with qualifications). It is also referenced the fact that these short training actions do not give diploma, that's why they often understand these sessions as a waste of time. In a study carried out by Pereira (2016) it is pointed out that in one specific Employment Centre in Portugal it was found that there had been Ciganos registered for periods of over a decade and had never been called in for a job or vocational training course. Parallel to this, the technicians interviewed equally acknowledged the lack of employment and training opportunities that fit Ciganos registered in Employment Centres (who often don't possess the minimum compulsory education) and the lack of openness of employers to accept these individuals. This situation is similar to what has been found in other European countries as well (Vincze 2006; IRS 2008).

Another aspect that is negatively perceived by the Ciganos interviewed is the concentration of this population in the same course or course type on the part of the IEFP. They reported cases in which Ciganos with different school and professional competences are all placed in the same class, where teaching is homogenised, most often levelled off at a more basic level of instruction, not accompanying the increase of acquired formal qualifications. As Bereményi (2011) argues, although educational policies focus on the issue of intercultural inclusion and education, in practice this is not the case. Cultural diversity, although often defended and referred to, is often a mere discursive rhetoric. Debate often focuses on students' academic competencies and not on global knowledge of culture, language, geography or different religions. The Ciganos, as "a different other" (otherness), is rarely described as someone who benefits from the learning process (Bereményi 2011, p. 362). Expectations on the

\footnotetext{
${ }^{5}$ The initiative New Opportunities was implemented in 2005 as a joint action of the Ministry of Labour and Social Solidarity and the Ministry of Education, having as its goal the diversification of educational and training paths, the strengthening of professional positions, and the promotion of a school courses and educational success. The New Opportunities program was replaced in 2014 by the Network of Centers for Qualification and Vocational Education.
} 
part of teachers towards this population is low, with Ciganos students almost always being placed on the lower ranks of hierarchical scales established by teachers; scales often constructed according to the preconception of perceived attitudes possessed by Ciganos towards school in which families are blamed for the lack of school success and disinterest. This may be the result of stereotyping on the part of the actors who work with the Ciganos in this realm. It is very plausible that unemployed Ciganos registered at Employment Centres are directly linked to SII benefits (and because of this, are often impelled to register). As well, work proposals are almost non-existent and training proposals are rare. Pertinent to training proposals, those that do exist are often considered undesirable or of little significance in terms of knowledge and skill acquisition, this along with the fact that their respective diplomas often holding little value (are often not recognise as school diploma or a professional or a diploma) (Pereira 2016).

Some of the Ciganos interviewed who possess more scholastic education (most of them men), stated that, presently, schooling is worse than it was in their time, and that in the case of their children they feel that school does not prepare them as well for the future, highlighting their children's learning of content they deem unnecessary. Greater expectations, therefore, are expressed regarding the schooling of their children, highlighting the need for better preparation when it comes to making professional choices in life. For these individuals, the need for school continuation and the value of a scholastic education is seen as a means to achieve a "good job" and not as an end in itself. Getting a job is thus considered a form of upward social mobility that ensures some economic stability.

When it comes to changing such perspectives and promoting the valorisation of schooling, certain public policies (such as compulsory education, the SII, etc.) as well as people of reference (family, friends, neighbours, mediators, etc.) are key actors/factors in encouraging school continuation. As mentioned, school continuity often takes place in stages, as opportunities arise. For some, especially males, schooling routes are only seen as important if there's a professional component. Still, it is important to emphasise that there is often a great amount of difficulty in placing students and trainees into internships upon course completion.

\section{(Mis)Matches of Perspectives on Schooling}

Brüggemann and D'Arcy (2016) synthesize two perspectives as put forward by much of the literature on the schooling of Ciganos: (1) some studies present theoretical assumptions concerning the educational disadvantages of minority group students (their parents and communities), centring theorisation on cultural and socio-economic differences and marginality; (2) other studies argue that inequality is triggered by features associated with policies and school institutions (institutional discrimination). The results of our fieldwork in the neighbourhoods and schools, relying especially on the interviews with the institutional actors, are included, above all, in the first group of studies. 
From a general perspective, the Ciganos known to the technicians interviewed are characterised by them as having low levels of education, high dropout rates and high levels of school absenteeism in the case of school aged children, the majority of which attend primary school. The main causes of high drop-out rates among Ciganos - as revealed by studies carried out in other countries as well, for example Bulgaria (World Bank 2014) and Romania (Ilisei 2013; Surdu and Surdu 2006) - is marriage, which among Ciganos takes place at very early ages; the social control and extreme concern of girl's education, especially after menarche; and, thirdly, the successive failures that often occur in primary school which frequently leads to the maladaptation of young Ciganos students when advancing to the next level of schooling. This is often due to the advanced age many find themselves at when completing primary schooling, in comparison to their non-Ciganos peers (Mendes 2007, 2012; Magano 2010; Nicolau 2010). Such poor results and consequent school failure are owed to a series of causes namely: poor socialisation skills; deficient cognitive stimulation; poor language resources; lack of motivation for learning; lack of expectations in relation to school; lack of role models and having no knowledge of Ciganos peers who have effectively completed certain levels of schooling, be it grade 9 or 12 (as evident in a small number of cases identified in MAP and MAL), or post-secondary education (in the cases we identified - all of which in the MALCiganos with university studies have one non-Ciganos parent); as well as being aware of the often lack of opportunities and impacts of schooling on professional life.

As pointed out in previous studies (Mendes 2007; Magano 2010; Nicolau 2010), girls tend to drop out of school earlier than boys. Still, signs of changing attitudes and behaviors concerning gender relations among Ciganos are becoming visible. Here they revealed the increasing participation of adult women in literacy courses (actions carried out or in progress at the time of the interviews), while other women were seeking to obtain Recognition, Validation and Competence Certificates ${ }^{6}$ (RVCC) with the aim of increasing their schooling levels.

Lifelong learning opportunities (Gomes 2013) are often stimulated by the SII teams and are very important for improving the living conditions of Ciganosparticularly that of Cigano women, as education, training and qualification may enable them to enter the labour market, to achieve greater social mobility, and to assist in establishing a departure from their traditional way of life (Magano 2010, 2014).

Regardless of the aforementioned changes, there are still numerous obstacles, such as the fact that men do not allow women to leave the neighborhood (Lopes 2006), just to name one. The obstacles identified require innovative and proximity

\footnotetext{
${ }^{6}$ The National System of Recognition, Validation and Competencies Certification (RVCC) was created in February, 2001, alongside with the National Agency of Adult Education and Training, through Ordinance no. 1082-A/2001 of the 5 of September. This initiative was made extinct at the start of 2013.
} 
solutions, in particular through the promotion of education and/or training at the local level and in partnership with credible entities who work with this population.

In the discourses provided by teachers and mediators, there is, on the one hand, a certain tendency towards stereotyping the Ciganos, while, at the same time, expressed difficulties in valuing the singularities and the positive aspects that can come from cultural coexistence in a school context, are evident. They are aware of gender differentiations when it comes to parents supporting their children's school continuity: girls are not encouraged to continue their education from a certain age or certain grade onward, instead are encouraged to abandon their studies in favour of cultural traditions associated with young Ciganos and the preparation for their marriage. This triad of gender, marriage and educational aspirations needs to be further analyzed, and new elements of cultural change must be considered by the younger Ciganos (Bereményi and Carrasco 2015).

As far as scholastic success is concerned, there are no great differences between Ciganos and non-Ciganos students during the primary school years. However, during grades 5 and 6 (second cycle), Ciganos students' absenteeism grows exponentially for reasons teachers cannot explain. Absenteeism contributes to school failure, the main factor given by for dropping out of school—often out of frustration of not being able to understand what is being taught to them. Ciganos students have little home study habits; learning is mainly carried out in the classroom context.

Some of the social policies that directly impact upon schooling, are, however, considered positive. For example, solutions like $\mathrm{ETPI}^{7}$ are seen as contributing to promoting school continuity and are positively perceived by Ciganos, even if the programme offers no prospects for the future. There is a tendency to perceive ETPI classes as classes consisting of and conceived for Ciganos, where ethnic concentration is the outcome (often perceived as a congregation of problems as well).

As previously mentioned, all schools that participated in this study had ongoing ETPI projects. However, in practical terms, the direct positive inputs associated with this programme are not very visible. The ETPI Programme is considered to be an important programme for Ciganos families and for the communities where they're implemented. Still, across the territories, the same two primary constraints in the programme's implementation are often mentioned: the lack of financial and human resources. This perspective is corroborated by the National Education Council (2014, p. 38), which equally defends that: "The contribution of the ETPI programme is considered moderately positive given the fragility of its results. This points to the need of re-evaluating the applied strategies, in favour of an intervention at the social and family (school-family articulation) levels."

All of the interviewed technicians referred to the importance of the SII when it comes to the school attendance of all Ciganos up until the end of primary schooling.

\footnotetext{
${ }^{7}$ Educational Territories of Priority Intervention Program is a government initiative, implemented in economically and socially disadvantaged territories, marked by poverty and social exclusion, where violence, indiscipline, dropping out and school failure are most evident. Central objectives of the program are the prevention and reduction of early school leaving and absenteeism, the reduction of indiscipline and the promotion of educational success for all students.
} 
Likewise, the majority of the Ciganos we interviewed stated that school is important for their children, claiming that it's important that they attend irrespective of the existence of the SII or not.

The truth, however, is that in stating this, they are referring to the once required basic schooling when they were at that age. At present, basic education is up to the ninth grade and the compulsory schooling was extended up to the 12th grade (18 years old, secondary school). Many Ciganos, however, still believe that mandatory school continues to be up to grade 6 (first and second cycles). So, there exist a big gap between the real compulsory school and the expectations of Ciganos in relation to the frequency.

The high levels of absenteeism and school drop-out rates are also of no surprise for the technicians and teachers. The majority pointed out the importance of the IETP courses, as well as the alternative school routes when it comes to children's and young people's school continuity, highlighting the importance of how course syllabuses can be more easily adapted to the interests of Ciganos students, and how students themselves can develop and discover new interests and motivations. The main limiting factors in the development of these measures and programmes are once again the lack of financial resources that have been reduced from one year to the next. As a consequence of this limited capital, this leads to a lack of human resources resulting in poor dedication given to programmes and students. Furthermore, schooling alternative measures are not always understood as positive: some teachers consider policies such as the IETP programme, the alternative schooling routes to be forms of segregation.

Due to mutual fear and misunderstanding, teachers admit that it is difficult for schools and teachers to deal with Ciganos families. This situation is not unlike what takes place in the Spanish context, inasmuch as according to Gamella (2011, p. 381): "the low expectations of teachers, especially in the first years of schooling, in relation to Gypsy pupils, leads to a complex interaction of prejudices, real experiences, both in school, in the relationships with families and with the students themselves. In any case, this has a decisive effect as self-fulfilling prophecies". Portuguese Ciganos children, no different from Ciganos children in other contexts, often learn in unfit, segregated environments, are frequently discriminated against by teachers and are often victims of hostile environments. There is a lack of a stimulating learning environment for these individuals, as well as positive reference models, factors that lead to high rates of school drop-out and failure. Consequently, in the case of Cigano women, for example, the lack of qualifications means that they often can't compete on the labour market, resulting in their outright "disempowerment" (Bitu and Morteanu 2010). But it is also very important to ensure the attendance of pre-school education as a way to stimulate the acquisition of previous skills such as language, mathematics and other areas by children from disadvantaged backgrounds (Luksik 2019). From the perspective of teachers and mediators, the very little value attributed to schooling and the negligent attitude towards school continuity on the part of the Ciganos, often leads to the validation of absence of the children-motives not permitted if used as a justification by non-Ciganos, therefore, are taken for granted when applied to this youth minority group. Consequently, this 
becomes a very difficult issue to understand and accept on the part of teachers, who see their efforts weakened by differences and cultural singularities difficult to overcome.

The majority of the teachers who participated in our study attribute the responsibility of grade failure and school abandonment to factors external to the school, blaming primarily on the family as is evident in the above testimonies. Many, therefore, do not see the scholastic lack of success of Ciganos children as a structural problem that can be solved by the schools and the educational system (Doubek et al. 2015). Parental responsibility (or lack thereof), along with the attribution of neglect and disinterest in relation to school, is a rhetoric transversal to a number different countries as has been made evident by Rostas and Kostka (2014) in their observation focusing on Central and Eastern Europe countries.

\section{Key Factors for Ciganos Educational Attainment}

Writing on the success stories of young Gypsies in Spain, Gamella (2011) presents a rational, interactive, dynamic, and procedural interpretive model, involving five crossover levels, to measure such success. These are: the individual/personal; the family environment (home, relatives, networks); school and teachers; the surrounding community, including peer groups, neighbours and community members (of which family and school are an integrated part); and last, but not least, the broad social level, be it of a local, regional, national and global scale. A previous study by Abajo and Carrasco (2004) suggested a very similar scheme. In addition to personal characteristics (e.g. school success, tenacity and personal commitment, social skills, among others), a socio-economic dimension is also added: residing in integrated, urban contexts, having a cohesive family and socio-economic stability; having access to social resources; as well as a school dimension: an integrated school context, positive school environment, family involvement in the education of the children, and a relational and associative dimension-e.g. a positive relationship with an intercultural context, having a peer group that surpasses the co-ethnic environment (neighbours, friends, etc.), among other aspects.

Our results show that school continuity paths are not dissociated from the greater importance attributed to the support and continuous personalised guidance on the part of those whose role it is to intervene, such as family support, incentive of teachers, support of "Godparents", etc. In addition, in some cases, there are individuals and/or families that give true value to schooling, to positive results, that care if their children miss classes or not, that the children possess a positive attitude, correct behaviour, and have that capacity to socialise and be motivated. As well, there were also cases of family support provided by parents who did not study but would have liked to, by parents who did study, by parents who are self-employed, those who employed by others and those who aren't employed at all. But there was also 
evidence of greater support given to boys (gender differentiation), where, in the case of girls, there is greater tolerance for school drop-out and often very little incentive is given for them to go to school.

School continuity differentiation among the gender groups (boys and girls) (Gamella 2011) is an issue of significant importance for the Ciganos s interviewed. It was highlighted the tendency for simultaneous school leaving by Ciganos children, for example ("I left (school) and they all followed me" (woman, 22-years-old, fifth grade). As a justification for this situation, the issue of gender in regards to the age of marriage and efforts made to protect girls from having contact with boys, be them Ciganos or otherwise, continues to be a highly referenced reason.

In relation to the Ciganos interviewed with more years of schooling, the progress was made in stages, through transitions between "cycles" from regular to alternative schooling (for many, there was always the possibility of taking advantage of measures that allowed grade advancement, namely professional courses, New Opportunities programme, RVCC). Among the adults there were no cases of school continuity through regular education to the 12 th grade. The regular path, however, is becoming more common among Ciganos youth currently enrolled in the school systems.

The arrival of "the age of marriage" is referred to as a factor that leads to fortified friendships taking place with other Ciganos, leading to greater ethnic clustering. As a result of this, in conjunction with the fact that most have failed more than one grade up to this point, many don't go beyond the 2 nd/third cycle of schooling. Very few remain in school after the age of 16 , be them boys or girls, the age often referred to as the crucial age of marriage preparation. There are some cases in which school continuation takes place through professional courses or training, routes that highlight the importance of such measures in permitting school continuity, be it in or outside of school. Ciganos often see school as a space to be frequented when one is a young child, not as an adolescent or as an adult. Although Ciganos mediators are seen as important when it comes to trying to do away such beliefs, in attempting to improve the relationship between Ciganos and school, and in supporting the building of bridges as attempts to safeguard and defend Gypsy culture, their function should not be one of "extinguishing fires", but, instead, to build relationships based on continuously intervention, something that is rarely takes place due to the precarious contractual nature and short-term durations of intervention projects.

A positive school environment and absence of local level conflicts (e.g. neighbourhood disputes) allow for greater continuous intervention when it comes to promoting incentives for going and staying in school. The same argument applies when a high concentration of Ciganos students in one classroom is non-existent. According to Abajo and Carrasco (2004), more positive are results in ethnically/racially mixed learning environments in which programmes are equally established for all, following a pre-established education programme for the respective level.

The need to actively search for work, due to ever-growing constraints in terms of developing more traditional professional activities (of a self-employed nature), along with the fact that many are beneficiaries of the SII, leads to some searching out more 
education or training, given that it's a requirement, not only in order to access gainful employment, but to keep receiving SII benefits. In order to frequent education/ training courses at the adult age, given that we are here talking about a group of people who get married and start families at a very early age, these individuals are than given access to an additional source of income (food and transport subsidies) that permits attending classes. Beyond these measures, however, it is important to point out that there's a gap between the real needs of unemployed Ciganos enrolled in the Employment Centres, the vocational training possibilities at offer and referrals for work proposals (Pereira 2016; Gatti et al. 2016).

To conclude, it is worth emphasising that certain perspectives regarding school are now taking place. For example, in the present day, the conclusion of primary school (first cycle) is a generalised phenomenon among younger generations. There has also been an increase in children enrolled in nursery and pre-schools. The persisting problem sits in the transition period between the first and second cycles (fourth to fifth grade). At this stage of education, children will sometimes transit from one cycle without having acquired the basic skills needed to succeed at the next level, thus hampering their chances of further advancement beyond this cycle, creating other problems as well such as limiting their diversity of disciplines and teachers. According to the National Education Council (2014, p. 38), the national early school leaving rate in Portugal (19.2\%) is very high when compared to that of the European Union (11.9\%), adding as well that the European targets for 2020 will be a great challenge for Portugal. This situation implies that there's a need to develop strategies, on one hand, to avoid abandonment, on the other, to reintegrate those who have abandoned the system. Taking into consideration the results of some of the strategies developed, it is advisable that actions to reduce school leaving be approached from various fronts in order to prevent the risk of abandonment (ensuring quality of education from the earliest years of life), to avoid it from happening (responding to warning signals and providing support), and to compensate those who desire to return to school (allowing easy re-entry into the system by recognising previous qualifications). In order for national strategies to be implemented, they should thus take into account data on disaggregation inequalities according to sex and region (CNA 2014).

It should also be noted that the levels of schooling established by law are very distant from the scholarly objective defined by the Ciganos interviewed. On this topic, basic skills acquired in primary school—e.g. the ability to read and write, essential in the carrying out of certain functions such as getting a drivers licenseare often valued. Opposite of that, what is perceived as the need for so many years of schooling and school attendance is not fully understood. As well, our Ciganos interviewees made reference to the fears often felt concerning school "insecurity" and the school environment, especially in relation to schools found in neighbourhoods marked by a history of conflict or a high presence of immigrant population.

The reasons given for early school leave relate, above all, to the issue of marriage and the preservation of women's "purity", letting it be known that Ciganos are generally at issue with certain teachings and syllabus content (for example, that of 
reproduction). That said however, there is also a clear differentiation when it comes to supporting school continuity on the part of the parents, a differentiation defined by gender. In general, early marriage and the birth of children interrupt a life of going to school and its continuity. Thus, once upon that stage of their lives, a regular schooling format is substituted by compensatory measures, professional courses/ training, a route often only taken when there are social protection benefits to be gained; in other words, when they are "forced" into such programmes.

In some Ciganos with more school education, the existence of disenchantment was made evident in the narratives collected, this owed to the lack of opportunities available to these individuals. Our interviewees explained that such difficulties were met in entering the labour market due to discrimination against Ciganos (Magano 2010; Mendes and Magano 2016).

\section{Conclusion}

The policies introduced in Portugal since the implementation of democracy contributed to the improvement of living conditions of Portuguese Ciganos, especially in the fight against extreme poverty and housing. There are, however, significant differences between the living conditions of Portuguese Ciganos and the Portuguese population in general, with old and new forms of social inequalities persisting in the form of poverty, poor living conditions, low levels of schooling, difficulties in accessing the labour market, uncertain ways of earning an income which often implies dependence on social benefits, among others. Ciganos in Portugal particularly continue to show marked levels of disadvantage, vis-à-vis other national citizens, especially when it comes to accessing and staying in school, accessing vocational training, employment, housing, public services and justice.

In Portugal, Ciganos continue to possess low schooling and professional qualification levels, well below the national average. Although younger generations now possess more school education and qualifications than that of their parents, they still experience strong constraints in accessing the labour market. When they do find work, often accomplished by hiding their ethnic identity, the majority still occupy unqualified posts. To teachers and mentors, however, Ciganos students and their families continue to be held accountable for the lack of interest, failure and school drop-outs. For the Ciganos, the issue of alternative school programme structures, methodologies and other pedagogical frameworks are not perceived as an exercise of power affirmation that benefits them. In fact, measures of applied educational policies (PIEF, TEIP, New Opportunities, etc.) are in large part seen as a way of agglutinating and segregating students into specific groups in which processes of learning and their evaluation are not worthy of much investment (Bereményi and Carrasco 2015).

The continuity of school trajectories often depends on public policies and programmes, yet other factors also emerge-it is important to consider the multiplicity of interactions and complex factors that are more specific to individuals, to the 
support they receive and outlook towards schooling on the part of the family, to the presence of role models in their lives, as well as the role of gender and institutional factors in the functioning of the public school. As Gobbo (2011, p. 39) highlights, "'schools' and classroom' changes are also produced by educational rules and expectations, as well as by students' and teachers' coping strategies' namely in (not always positive) interaction with the cultures of schools, which are themselves culturally and historically situated".

According to Powell and Lever (2017), based on Norbert Elias and Loïc Wacquant theories, the present and contemporary Roma situation can overshadow the historical continuities in terms of the collective treatment of Roma as an inferior group, which is a central issue to understand their constant and severe stigmatization. That is invariably dependent on asymmetric power relations and the effective construction of Roma as an inferior and different group. Even when Roma pupils are educated in an 'inclusive' school or classroom, their position continues to be that of outsiders.

\section{References}

Abajo, J. E., \& Carrasco, S. (Eds.). (2004). Experiencias y trayectorias de éxito escolar de gitanas y gitanos en España. Encrucijadas sobre educación, género y cambio. Cultural. Madrid: Instituto de la Mujer (MTAS) and CIDE (MEC), Colección Mujeres en la Educación.

ACIDI. (2013). Estratégia Nacional para a Integração dos Ciganos. Lisbon: Alto Comissariado para a Imigração e Diálogo Intercultural/ACIDI.

Bastos, J., Correia, A., \& Rodrigues, E. (2007). Sintrenses ciganos. Uma abordagem estruturaldinâmica. Lisboa e Sintra: ACIDI e Câmara Municipal de Sintra.

Beaud, S., \& Weber, F. (1997). Guide de l'enquête de terrain. Paris: La Découverte.

Bereményi, B. Á. (2011). Intercultural policies and the contradictory views of teachers: The Roma in Catalonian schools. Intercultural Education, 22(5), 355-369. https://doi.org/10.180/ 14675986.2011.643134.

Bereményi, B. Á., \& Carrasco, S. (2015). Interrupted aspirations: Research and policy on Gitano education in a time of recession, in Spain. Intercultural Education, 1-12. https://doi.org/10. 1080/14675986.2015.1028166.

Bitu, N., \& Morteanu, C. (2010). Are the rights of the child negotiable? The Case of early marriages within Roma communities in Romania. Bucareste: UNICEF Romania.

Brüggemann, C. (2014). Romani culture and academic success: Arguments against the belief in a contradiction. Intercultural Education, 25(6), 439-452. https://doi.org/10.1080/14675986. 2014.990229.

Brüggemann, C., \& D'Arcy, K. (2016). Introduction. Contexts that discriminate: International perspectives on the education of Roma students. Race Ethnicity and Education, 1-4. https:// doi.org/10.1080/13613324.2016.1191741.

CNA-Conselho Nacional de Educação. (2014). Estado da Educação 2013. Lisboa: Conselho Nacional de Educação.

CPESC (Comissão Parlamentar de Ética, Sociedade e Cultura). (2009). Relatório das Audições efectuadas sobre ciganos portugueses no âmbito do Ano Europeu para o Diálogo Intercultural. Lisboa: Assembleia da República.

DGEEC - Direção Geral de Estatísticas da Educação e Ciência. (2018). Perfil Escolar da Comunidade Cigana 2016/17. Lisboa: DGEEC. 
Doubek, D., Levínshá, M., \& Bittnerová, D. (2015). Roma as others. Intercultural Education, 26 (2), 132-152. https://doi.org/10.1080/14675986.2015.1027084.

European Parliament. (2011). National Roma integration strategies. European Parliament resolution (2010/2276 (INI)). Strasbourg: European Parliament.

Gamella, J. (2011). Historias de éxito. Modelos para reducir el abandono escolar de la adolescencia gitana. Madrid: Ministerio de Educación, Secretaría de Estado de Educación y Formación Profesional, Instituto de Formación del Profesorado, Investigación e Innovación Educativa (IFIIE).

Gatti, R., et al. (2016). Being fair, faring better-Promoting equality of opportunity for marginalized Roma. Washington, DC: World Bank.

Gobb, F. (2011). Ethnographic research in multicultural educational contexts as a contribution to intercultural dialogue. Policy Futures in Education, 9(1), 5-42. https://doi.org/10.2304/pfie. 2011.9.1.35.

Gomes, M. C. (2013). Políticas públicas de qualificação de adultos e comunidades ciganas. Movimentos inclusivos. In M. Mendes \& O. Magano (Eds.), Ciganos Portugueses: Olhares plurais e novos desafios numa sociedade em transição (pp. 81-91). Lisboa: Editora Mundos Sociais.

Ilisei, I. (2013). Education of Roma women between feminism and multiculturalism case study: Roma women in Romania. Journal of Social Science Education, 12(1), 67-74. https://doi.org/ $10.4119 /$ jsse- 636 .

Instituto Per La Ricerca Sociale. (2008). The social situation of the Roma and their improved access to the labour market in the EU. Retrieved from http://www.europarl.europa.eu/document/ activities/cont/201107/20110718ATT24290/20110718AT T24290EN.pdf

Lopes, D. S. (2006). Deriva cigana. Uma etnografia impressionista. Lisboa: Universidade Nova de Lisboa. Faculdade de Ciências Sociais e Humanas.

Luksik, I. (2019). Children from marginalised Roma communities at the school gates: The disconnect between majority discourses and minority voices. Early Childhood Education Journal, 47, 665-675. https://doi.org/10.1007/s10643-019-00959-z.

Magano, O. (2010). «Tracejar vidas normais». Estudo qualitativo sobre a integração social de indivíduos de origem cigana na sociedade portuguesa (Tese de Doutoramento, Universidade Aberta, Portugal).

Magano, O. (2014). Tracejar «vidas normais». Estudo qualitativo sobre a integração dos ciganos em Portugal. Lisboa: Editora Mundos Sociais.

Marques, J. F. (2013). O racismo contra as coletividades ciganas em Portugal: sequelas de uma modernização. In M. Mendes \& O. Magano (Eds.), Ciganos Portugueses: Olhares Plurais e Novos Desafios numa Sociedade em Transição (pp. 111-121). Lisboa: Editora Mundos Sociais.

Mendes, M. M. (2007). Representações Face à Discriminação. Ciganos e Imigrantes Russos e Ucranianos na Área Metropolitana de Lisboa (Tese de Doutoramento, Instituto de Ciências Sociais da Universidade de Lisboa, Portugal).

Mendes, M. M. (2012). Identidades, Racismo e Discriminação: ciganos da Área Metropolitana de Lisboa. Lisboa: Caleidoscópio.

Mendes, M. M., \& Magano, O. (2016). School pathways and economic practices of Portuguese Ciganos: Some continuities and change. Social Identities, 22, 1-16. https://doi.org/10.1080/ 13504630.2016.1186537.

Mendes, M. M., Magano, O., \& Candeias, P. (2014). Estudo Nacional sobre as Comunidades Ciganas. Lisboa: ACM.

Mendes, M. M., Magano, O., \& Candeias, P. (2016). Social and spatial continuities and differentiations among Portuguese ciganos: Regional profiles. Studia Ubb Sociologia, 61(LXI), 1, 5-36. doi:https://doi.org/10.1515/subbs-2016-0001.

National Education Council. (2014). Estado da Educação 2013. Lisboa: Conselho Nacional de Educação.

Nicolau, L. (2010). Ciganos e Não Ciganos em Trás-os-Montes: Investigação de um Impasse Interétnico (Tese de Doutoramento, Universidade de Trás-os-Montes e Alto Douro, Portugal). 
Pereira, I. (2016). “Ninguém dá trabalho aos ciganos!”. Estudo qualitativo sobre a (des)integração dos ciganos no mercado formal de emprego (Tese de Mestrado, Universidade Aberta, Portugal).

Powell, R., \& Lever, J. (2017). Europe's perennial 'outsiders': A processual approach to Roma stigmatization and ghettoization. Current Sociology, 65(5), 680-699. https://doi.org/10.1177/ 0011392115594213

Rostas, I., \& Kostka, J. (2014). Structural dimensions of Roma school desegregation policies in central and Eastern Europe. European Educational Research Journal, 13(3), 268-281. https:// doi.org/10.2304/eerj.2014.13.3.268.

Surdu, L., \& Surdu, M. (2006). Broadening the agenda: The status of Romani women in Romenia. New York: Open Society Institute.

Vincze, E. M. (2006). Social exclusion at the crossroads of gender, ethnicity and class. A view of Romani Women's reproductive health. Budapest: Central European University.

World Bank. (2014). Gender dimension of Roma inclusion. Perspectives from four Roma communities in Bulgaria. Europe and Central Asia Social Unit: World Bank Group.

Open Access This chapter is licensed under the terms of the Creative Commons Attribution 4.0 International License (http://creativecommons.org/licenses/by/4.0/), which permits use, sharing, adaptation, distribution and reproduction in any medium or format, as long as you give appropriate credit to the original author(s) and the source, provide a link to the Creative Commons licence and indicate if changes were made.

The images or other third party material in this chapter are included in the chapter's Creative Commons licence, unless indicated otherwise in a credit line to the material. If material is not included in the chapter's Creative Commons licence and your intended use is not permitted by statutory regulation or exceeds the permitted use, you will need to obtain permission directly from the copyright holder.

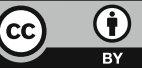

